\title{
MOTIF TRADISI WAYANG KHAS BALI PADA PENCIPTAAN SENI KERAMIK
}

\author{
I Wayan Mudra ${ }^{1^{*}}$, I Gede Mugi Raharja ${ }^{2^{*}}$, I Wayan Sukarya ${ }^{3^{*}}$ \\ Program Studi Kriya, Program Studi Desain Interior, dan Program Studi Seni Murni \\ Fakultas Seni Rupa dan Desain \\ Institut Seni Indonesia Denpasar \\ Jl. Nusa Indah, Sumerta, Kota Denpasar, Kode Pos 80235 \\ Bali. Indonesia \\ Email: wayanmudra@isi-dps.ac.id
}

\begin{abstract}
Abstrak
Para pencipta karya keramik di Indonesia terlihat telah berusaha mengangkat muatan tradisi khas Indonesia untuk mengimbangi dominasi kuasa produk keramik image Cina yang ada di Indonesia. Wayang khas Bali adalah salah satu motif tradisi yang sering dipilih dalam menciptakan karya-karya kriya keramik ini. Penulisan atikel ini bertujuan untuk membahas penciptaan karya-karya keramik yang terinspirasi dari motif wayang khas Bali. Penelitian ini memfokuskan bahasan pada jenis-jenis karya yang diwujudkan, teknik pembentukan, teknik penerapan ornamen, tokoh-tokoh wayang khas Bali yang divisualkan dan kualitas garapan dari karya-karya tersebut. Metode pengumpulan data dilakukan dengan observasi dan dokumentasi, analisis data dilakukan dengan deskriptif kualitatif. Hasil penelitian menunjukkan bahwa karya-karya yang diwujudkan pada penciptaan keramik ini jenisnya terdiri dari guci dalam berbagai variasi dan ukuran, tempat lampu, dan dalam bentuk lukisan. Teknik pembentukan karya dikerjakan dengan teknik putar dan slab, dan penerapan ornamen dikerjakan dengan teknik lukis, ukir, dan toreh. Tokoh-tokoh wayang yang dominan dipilih dalam penciptaan ini, diambil dari seri ceritera Ramayana maupun Mahabrata, misalnya tokoh Rama, Sinta, Laksmana, Anoman, Bima, dan Arjuna. Kualitas garapan karya masing-masing pencipta cukup baik. Hal ini bisa dilihat dari kerapian garapan dan kerumitan bentuk ornamen. Simpulan yang dapat disampaikan bahwa karya-karya keramik hasil ciptaan ini mampu menjadi pembeda ditengah maraknya keramik bernuansa Cina di Indonesia.
\end{abstract}

Kata Kunci: ornamen; wayang; penciptaan; seni; keramik.

\begin{abstract}
The ceramic creators in Indonesia seems to have tried to lift the content of the typical Indonesian tradition to offset the power dominance of the Chinese image ceramic products in Indonesia. The Balinese puppets were one of the traditional motifs often chosen to creating these ceramics crafts. The article writing aims discussed the ceramic work's creation inspired by Balinese puppet motifs. This research focused on the types of works that are realized, the formation techniques, the applying ornaments techniques, the character figures that visualized and the quality of the works. The data collection method was done by observation and documentation, data analysis done with qualitative descriptive. The results showed that the ceramic works embodied consisted of jars in various variations and sizes, places of lights, and in the form of paintings. The technique forming work is done with swivel and slab techniques, and the ornaments application was done by painting, carving, and incising techniques. The dominant puppet characters chosen in this creation were taken from the Ramayana and Mahabharata stories, for example, the characters Rama, Sinta, Laksmana, Anoman, Bima, and Arjuna. The work quality of each creator was quite good. This can be seen from the neatness of the claim and the form complexity of the ornaments. The conclusions that can be conveyed were that the ceramics produced were able to make a difference in the midst of the rise of Chinese nuanced ceramics in Indonesia.
\end{abstract}

Keywords: ornaments; puppet; creation; art; ceramic.

\section{PENDAHULUAN}

Kehadiran karya keramik ada yang berfungsi pakai, ada yang berfungsi hias untuk memperindah ruangan dan ada yang berfungsi pakai dan hias. Keramik juga dapat dipandang sebagai karya seni berupa dua dimensi atau tiga dimensi (Susanto dalam Isnaini, 2016:137). Demikian juga karya keramik dapat dipahami sebagai karya untuk menyampaikan ekspresi seni, sehingga ada sebutan keramik seni dan seni keramik yang pada akhirnya keduanya bernilai ekonomi.

Para era globalisasi saat ini pembuatan benda-benda keramik oleh perajin di Indonesia telah banyak 
dipengaruhi oleh kebutuhan pasar, sehingga jati diri yang menjadi tradisi produk kerajinan sebelumnya makin lama makin tenggelam dan bergeser kebentukbentuk inovatif yang mengabdi pada kebutuhan pasar. Pasar memiliki kuasa besar dalam mengubah haluan perajin dalam menghasilkan karya. Akhirnya muncullah produk-produk kriya yang menekankan komsumsi, ekonomi dan individual yang terlepas dari muatan tradisi sebelumnya. Muatan tradisi sebelumnya sering dianggap mengekang kebebasan berinovasi, sehingga harus ditinggalkan demi mengabdi pada kebutuhan pasar. Pada era global ini manusia diyakini lemah dalam menghargai tradisi dan mudah meninggalkan tradisi, karena dianggap tidak sesuai zamannya (Mudra, dkk, 2019:184).

Terkait dengan hal di atas Martono mencontohkan produk-produk kriya keramik Kasongan telah dipengaruhi oleh barat, karena pasarnya yang produktif datang dari Eropa. Bentuk-bentuk kriya keramik khas Kasongan yang sebelumnya ada seperti kuda beban, naga, dan bentuk desain lainnya, semakin sulit ditemukan di sentra perajin. Demikian juga jenis produk kriya lainnya di daerah-daerah di Indonesia seperti kuningan di Juwana Pati, kriya logam Mojokerto, Boyolali dan sebagainya (Martono, 2010:23).

Pencipta kriya yang khusus menekuni kriya keramik dalam berkarya kecendrungannya mengarah ke kriya keramik seni. Mereka para kriyawan Indonesia ini dalam berkarya melakukan inovasi yaitu dengan mengangkat unsur-unsur muatan lokal yang ada di suatu daerah. Seniman keramik Indonesia seperti: F Widiyanto, Suhaemi, Hildawati, Legganu dan Hendrawan, beberapa diantaranya banyak yang mengangkat identitas lokal Indonesia. F. Widayanto adalah satu seniman yang lahir di Jakarta 1953, menekuni pembuatan keramik sering menampilkan karya bernuansa khas Indonesia. Karyakarya keramik F. Widayanto yaitu Loro Blonyo, Ganesha-Ganeshi, Drupadi, Semar, dan lain-lain. Namun seniman-seniman keramik tersebut masih jarang yang mengangkat motif wayang Indonesia khususnya wayang khas Bali sebagai ide penciptaan dalam berkarya. Tujuan penulisan ini adalah untuk mengkaji jenis-jenis karya yang diwujudkan, teknik pembentukan, teknik penerapan ornamen, tokoh-tokoh wayang khas Bali yang divisualkan dan kualitas garapan dari karya-karya tersebut.

\section{KAJIAN TEORI}

Kesenian wayang di Indonesia dapat dijumpai dalam bentuk wayang kulit yang dapat dijadikan sumber inspirasi untuk berkarya. Wayang kulit adalah satu di antara budaya seni Indonesia yang beragam dan diyakini sebagai kebudayaan asli Indonesia. Penyelidikan Profesor Kern dan Brandes menunjukkan, bahwa wayang diperkaya dan dibesarkan oleh kebudayaan Hindu. Akan tetapi, wayang yang ada di Indonesia tidak terpaku pada epos India, karena sudah disesuaikan dengan kebudayaan Indonesia (Mulyono, 1978: 9). Wayang kulit yang dipentaskan maupun yang diwujudkan dalam karya seni rupa di Indonesia memiliki motif bentuk yang berbeda-beda bagi setiap daerah dan tidak semua daerah memiliki tradisi menekuni kesenian wayang.

Di daerah Bali, pertunjukan wayang sudah ada sejak abad ke-9. Hal ini dapat diketahui dari Prasasti Bebetin, yang menjelaskan bahwa di Bali sudah ada pertunjukan wayang pada masa pemerintahan Raja Ugrasena, Tahun Saka 818 atau 896 Masehi (Tim Penyusun, 1974/1975: 23). Goslings (dalam Arthanegara, 1977: 3) bahkan menyatakan, bahwa wayang Bali lebih tua dari pada wayang Jawa, karena bentuk relif wayang pada Candi Jago (abad ke-13) di Desa Tumpang dekat Malang, mirip bentuknya dengan wayang Bali. Sedangkan pada bangunanbangunan kuno di Jawa tidak ditemukan relief bermotif wayang Jawa. Pada saat Raja Gelgel, Dalem Ketut Semara Kepakisan, diundang muntuk menghadiri Upacara Crada di Kerajaan Majapahit pada 1362, diberi hadiah sekotak wayang waktu pulang ke Bali (Kanta, 1977/ 1978: 10). Demikian pula pada masa pemerintahan Dalem Waturenggong, Raja Majapahit juga memberi hadiah sekotak wayang (Arthanegara, dkk, 1980/1981: 11).

Berdasarkan bukti-bukti yang ada, maka wayang telah diakui oleh Organisasi Pendidikan, Keilmuan, dan Kebudayaan Perserikatan Bangsa-Bangsa (UNESCO) 7 November 2003, sebagai pertunjukkan bayangan boneka tersohor milik Indonesia, warisan mahakarya dunia yang tak ternilai dalam seni bertutur (Masterpiece of Oral and Intangible Heritage of Humanity) (Nurgiyantoro, 2011:7). Wayang memiliki nilai yang tinggi bagi kehidupan manusia sehingga diakui sebagai karya yang agung. Demikian juga tokoh-tokoh dan ceritera wayang sarat dengan nilainilai kehidupan manusia yang perlu diteladani dan dihindari. Maka dari itu sangatlah tepat diterapkan dalam penciptaan sebuah karya seni untuk bisa menyampaikan karakter kehidupan kepada masyarakat luas, seperti yang dilakukan dalam penciptaan karyakarya seni keramik. 


\section{METODE PENELITIAN}

Tulisan ini merupakan hasil penelitian yang dilakukan dengan metode deskriptif kualitatif. Penelitian ini termasuk penelitian sampel, pengambilan data dilakukan di Kota Denpasar, khususnya pada Perguruan Tinggi Institut Seni Indonesia Denpasar. Pengumpulan data dilakukan dengan teknik observasi dan dokumentasi, serta penentuan sumber data dengan proposive sampling yaitu sesuai dengan tujuan peneliti. Analisis data menggunakan metode hermeneutik, yaitu menginterpretasi teks atau subjek penelitian yaitu visual karya-karya keramik yang terinspirasi dari motif wayang khas Bali. dalam karyakaryanya.

\section{HASIL DAN PEMBAHASAN \\ 1.Hasil}

Beberapa pencipta kriya keramik yang telah menerapkan wayang motif khas Bali dalam penciptaan kriya keramik adalah I Wayan Mudra dan I Gede Yuliawan. Kedua pencipta ini adalah pencipta dari kalangan akademik yaitu Program Studi Kriya Fakultas Seni Rupa dan Desain Institut Seni Indonesia Denpasar.

Mudra menciptakan beberapa karya keramik yang terinspirasi dari motif wayang khas Bali telah dilakukan mulai tahun 2018 sampai tahun 2019. Penciptaan ini merupakan realisasi dari Penelitian Penciptaan dan Penyajian Seni (P3S) dari Kemenristekdikti Republik Indonesia yang didanai 2018 dan 2019. Perwujudan karya ini melibatkan dua mitra, yaitu Tri Surya Keramik untuk proses pembentukan badan keramik dan proses pembakaran, dan untuk penerapan dekorasi dengan teknik lukis melibatkan mitra I Wayan Roky.

Karya-karya yang diwujudkan oleh Mudra terdiri dari guci dan sangku yang divariasikan dalam beberapa bentuk dan ukuran. Motif wayang khas Bali diterapkan pada karya keramik dengan teknik lukis. Ide-ide penciptaan karya-karya yang diwujudkan terinspirasi dari bentuk gerabah Lombok, gerabah Yogyakarta yang dipasarkan di Bali yang banyak diperdagangkan di Desa Kapal Kecamatan Mengwi Kabupaten Badung Bali. Sedangkan penciptaan produk lainnya terinspirasi dari bentuk benda yang disebut sangku. Sangku dalam keseharian masyarakat Bali digunakan sebagai tempat air suci (tirta) pada saat melaksanaan upacara keagamaan. Selain di Bali, sangkau juga diduga masih digunakan sebagai perangkat upacara di daerah Tengger dan umumnya terbuat dari bahan logam. Sangku di daerah Tengger disebut prasen (Atika, 2017).
Keramik ciptaan Mudra ini dibentuk dengan teknik putar (elektrick wheel) dan tiga kali proses tahapan pembakaran yaitu pertama tahapan pembakaran bisquit, kedua tahap pembakaran glasir dan ketiga tahap pembakaran ornamen. Penerapan ornamen pada karya ini dilakukan dengan teknik lukis pada permukaan badan keramik. Objek ornamen yang dipilih adalah tokoh-tokoh motif wayang khas Bali dari ceritera Ramayana yang masih terkait dalam satu cerita singkat. Adegan cerita pewayangan tersebut berusaha menampilkan cerita yang memiliki nilai-nilai kebaikan dan toleransi.

Satu dari beberapa karya Mudra berjudul "Guci Sugriwa Subali" seperti terlihat pada gambar 1 di bawah, berbentuk silinder berukuran tinggi $70 \mathrm{~cm}$ dan garis tengah badan $45 \mathrm{~cm}$. Karya ini dibuat dengan teknik putar dalam tiga kali sambungan, artinya pembuatan badan keramik ini terdiri dari 3 tahapan. Tahapan pertama membuat badan keramik bagian bawah yang sering disebut bagian pantat, tahap kedua membentuk badan keramik bagaian tengah dan ketiga membentuk badan keramik bagian kepala. Kemudian dalam keadaan masih plastis bagian-bagian badan keramik tersebut disambung membentuk satu badan keramik yang utuh, terakhir dibentuk bagian tutup. Secara keseluruhan proses pembentukan badan keramik ini terdiri dari empat tahapan. Setelah proses pembentukan selesai dilanjutkan dengan proses pembakaran bisquit atau proses pembakaran pertama, kemudian proses pembakaran glasir transparan. Tahapan selanjutnya adalah proses penerapan ornamen motif wayang khas Bali yaitu style wayang Kamasan. Penerapan ornamen ini dilakukan dengan teknik lukis. Proses terakhir dari perwujudan keramik ini adalah proses pembakaran ornamen dengan suhu mencapai 1000 oC.

Pada karya "Guci Sugriwa Subali" ini diterapkan ornamen tokoh wayang bernama Sugriwa, Subali dan Rama. Tokoh Sugriwa dan Subali yang kakak beradik ini sesuai kisahnya digambarkan sedang perang antar saudara, berlangsung dengan sengit dan tidak ada yang mau mengalah. Kedua tokoh digambarkan pada beberapa sisi badan keramik yang dibagi menjadi dua bagian yaitu bagian atas dan bawah. Tokoh Rama kemudian mengakhiri pertarungan tersebut dengan memanah Subali hingga tewas.

I Gede Yuliawan, seorang pencipta keramik seni dalam berkarya juga terinpirasi dari motif wayang khas Bali yang diwujudkan dalam bentuk karya-karya tempat lampu. Bentuk-bentuk karya Yuliawan terdiri 
dari beberapa desain tempat lampu diberi judul sesuai dengan figure wayang yang divisualkan pada karyakaryanya, misalnya Tempat Lampu Hanoman dan Rahwana, Tempat Lampu Rama dan Laksmana, Tempat Lampu Rama Dan Sita, Tempat Lampu Sugriwa dan Subali, Tempat Lampu Jetayu, Tempat Lampu Anggada dan Hanoman, Tempat Lampu Hanoman, Tempat Lampu Rahwana, Tempat Lampu Anggada dan Subali, dan Tempat Lampu Rama Memanah Kijang. Beberapa karya Yuliawan dibentuk dengan teknik putar dan beberapa karya lainnya dibentuk dengan teknik cetak. Ornamen motif wayang khas Bali diterapkan dengan teknik tempel, ukir, dan toreh, sedangkan proses finishing dilakukan dengan pengglasiran pada badan keramik sebagai latar belakang dan pemberian warna non glasir pada objek wayang. Karya-karya tempat lampu ciptaan Yuliawan dilengkapi dengan penutup atas terbuat dari kain

Rama dan Sita dalam cerita Ramayana. Badan keramik tempat lampu ini dibuat berbentuk kotak yang mengecil pada bagian atas, dan dibuat dengan teknik slab. Penerapan ornamen figur wayang dikerjakan dengan teknik toreh dan ukir. Badan keramik tempat lampu ini diglasir berwarna hitam dan pada bagian ornamen difinishing dengan cat minyak keramik dengan teknik sigar. Pada karya ini juga ditambahkan alas dari bahan kayu pada bagian bawah karya, bentuknya disesuaikan dengan bentuk persegi badan keramik bagian bawah. Pada karya ini digambarkan saat pengasingan Rama, Sita, dan Laksmana di hutan. Saat itu seekor kijang berbulu keemasan berjalan mendekati Sita, dan Sita mencoba menangkapnya tetapi gagal dan kijangpun lari. Sita meminta Rama menangkap kijang, akhirnya Sita tinggal sendiri di tempat karena ditinggal Rama menangkap kijang yang lari. Laskmana juga ikut membantu Rama menangkap kijang. Pada saat Sita ditinggal oleh Rama dan Laksmana, saat itu Sita diculik Rahwana dan dibawa ke Alengka, (Sudjarwo, dkk, 2010: 346-368).

Karya keramik lain yang terinpirasi dari motif wayang khas Bali adalah karya hiasan dinding yang terdiri dari sembelan bentuk tegel, kemudian dibingkai seperti karya lukisan terlihat pada gambar 4 di bawah. Karya ini merupakan koleksi Balai Teknologi Industri Kreatif Keramik (BTIKK) Bali. Tokoh wayang yang diangkat sebagai objek utama pada karya ini adalah Sita dan seorang Resi, dibuat dengan teknik tempel dan ukiran tipis sehingga menyerupai pandil. Pada karya ini juga digambarkan objek pohon besar yang diposisikan pada sisi bagian kiri dan kanan. Motif daun pohon dibuat dengan motif yang berbeda untuk
Gorga Jurnal Seni Rupa

Volume 08 Nomor 02 Juli-Desember 2019 p-ISSN: 2301-5942 | e-ISSN: 2580-2380

diberi ornamen motif wayang Kamasan. Penerapan ornamen motif wayang pada penutup tempat lampu ini bertujuan untuk membuat keselarasan ornamen antara bodi keramik dengan kap lampunya.

Gambar 2 karya "Tempat Lampu Hanoman dan Rahwana" di bawah, didekorasi menggunakan teknik toreh dan ukir, pewarnaan menggunakan glasir warna ivory sebagai warna dasar pada badan tempat lampu, Sedangkan warna figur tokoh Hanoman dan Rahwana menggunakan cat warna sintetis diterapkan dengan teknik sigar. Pada bagian bawah badan tempat lampu ini dikombinasikan dengan kayu yang bentuknya disesuaikan dengan badan keramik yang berfungsi sebagai dudukan dan tempat memasang kabel lampu.

Karya Yuliawan lainnya gambar 3 di bawah berjudul "Tempat Lampu Rama Sinta", memvisualkan tokoh memunculkan keragaman bentuk pada latar belakang karya. Sedangkan pada bagian bawah objek karya divisualkan tanaman-tanaman kecil dan bentuk-bentuk bebatuan yang digambarkan lingkaran-lingkaran dalam bentuk kekarangan. Karya ini menampilkan kerapian dan kerumitan yang cukup tinggi dan penerapan warna lembut dengan teknik lukis.

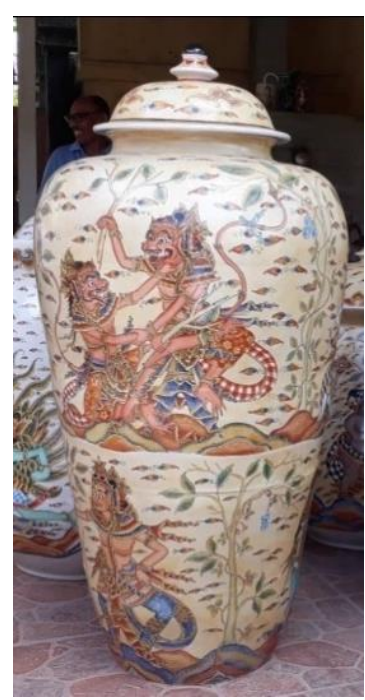

Gambar 1. Guci Subali Sugriwa (Sumber: Mudra, 2018) 


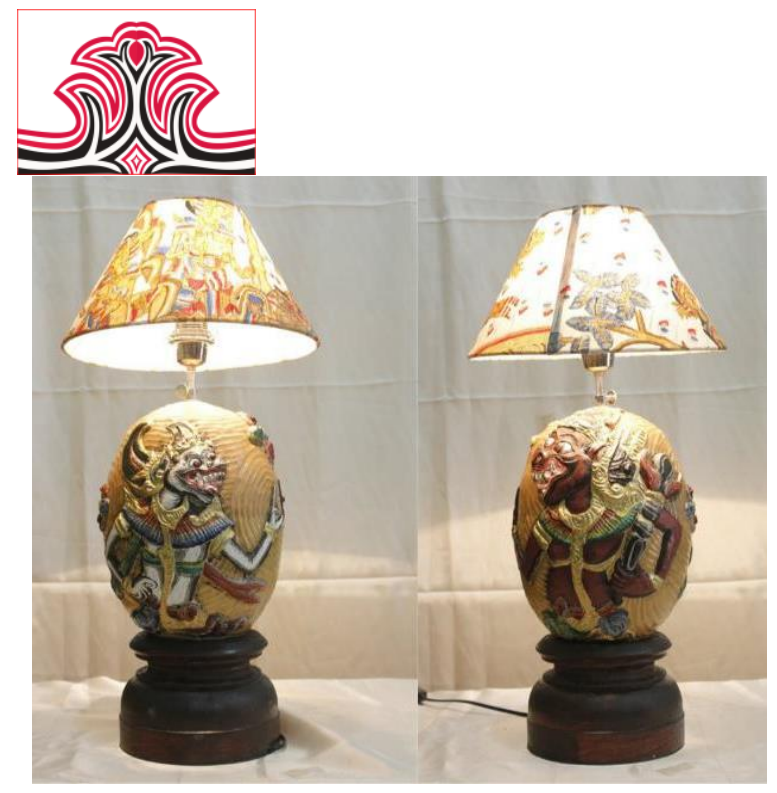

Gambar 2. Tempat Lampu Hanoman dan Rahwana. (Sumber: Yuliawan, 2015)

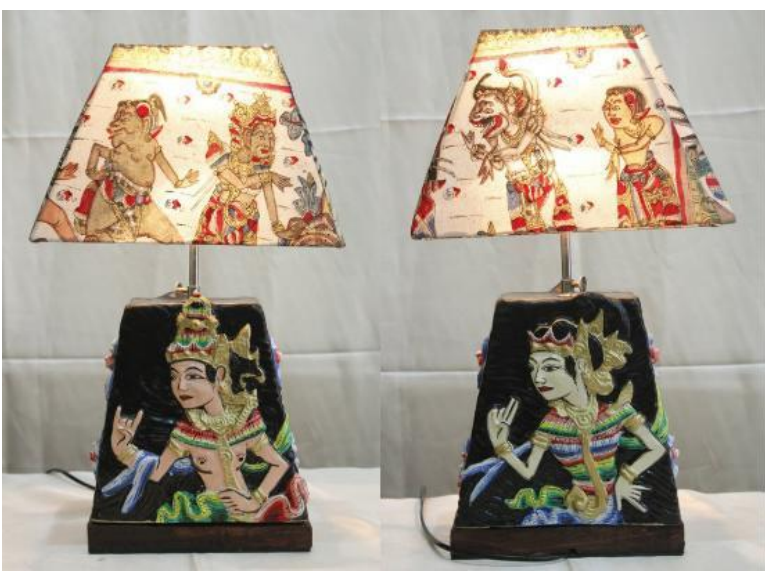

Gambar 3. Tempat Lampu Rama dan Sinta. (Sumber: Yuliawan, 2015)

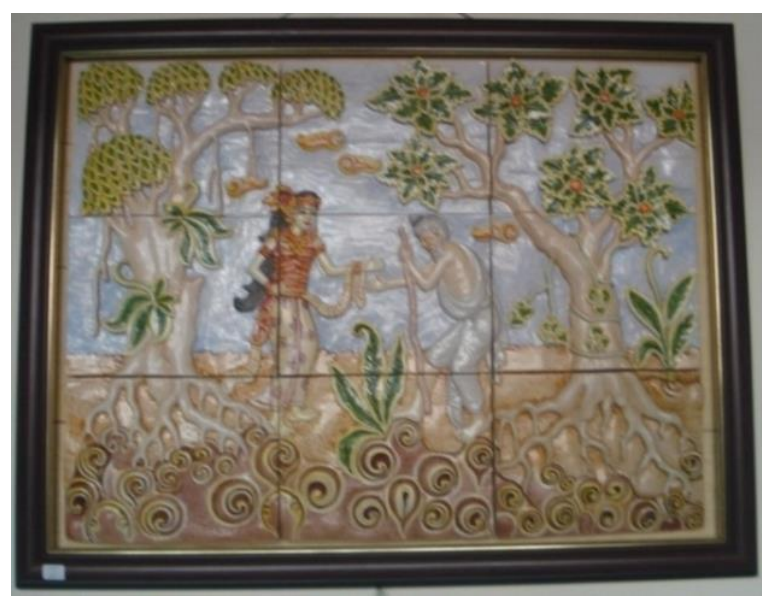

Gambar 4. Hiasan Dinding Keramik Ornamen Sinta dan Pendeta. (Sumber: BTIKK Bali, -----------)

\section{Pembahasan}

Penciptaan karya-karya Mudra ini lebih cendrung menghadirkan fungsi hias dibandingkan fungsi praktisnya atau nilai gunanya. Fungsi hias yang dimaksud adalah nilai-nilai keindahan dan kerumitan dalam perwujudannya dibandingkan nilai fungsi dari karya tersebut. Penilaian tersebut diperoleh jika mengacu kepada pendapat Husen Hindrayana (2018:6)
Gorga Jurnal Seni Rupa

Volume 08 Nomor 02 Juli-Desember 2019

p-ISSN: 2301-5942 | e-ISSN: 2580-2380

yang mengelompokkan karya seni kriya menjadi tiga yaitu karya seni yang cendrung menghadirkan nilai keindahan, kualitas teknik pengerjaan dan fungsi. Ornamen motif wayang khas Bali yang dibuat dengan kerumitan yang cukup tinggi memang dihadirkan untuk memunculkan nilai keindahan.

Ornamen motif wayang khas Bali yang ditampilkan berusaha divisualkan semaksimal mungkin memiliki motif karakter Bali yang sering dikenal sebagai lukisan wayang gaya Kamasan. Lukisan wayang gaya Kamasan ini telah menjadi acuan dalam menggambar wayang dan menghasilkan berbagai produk kriya di Bali. Lukisan wayang Kamasan adalah lukisan tradisi yang berkembang di Desa Kamasan Kabupaten Klungkung Bali, memiliki identitas yang sangat khas dan unik, terikat oleh pakem, nilai, norma, dan ketentuan yang bersifat mengikat dan baku (Mudana, 2017). Dengan demikian penciptaan karya keramik ini memiliki tujuan untuk menampilkan keindahan bentuk yang khas melalui ornamen wayang Kamasan yang divisualkan pada badan keramik dengan penerapan teknik lukis.

Tokoh Subali dan Sugriwa pada guci karya Mudra di atas, dalam episode Ramayana sering muncul pada lakon Guwarsa Guwarsi, atau lakon Sugriwa Subali, atau sering disebut dengan lakon Cupu Manik Astagina. Lakon tersebut cukup popular di kalangan penggemar wayang kulit. Subali dalam cerita pewayangan digambarkan sebagai tokoh yang memiliki watak keras, pemarah, temperamen, tanpa berfikir panjang dalam memutuskan segala sesuatu. Serat Pedalangan Ringgit Purwa (Mangkunegara VII: 74) menulis pada adegan ketika Subali terkurung di dalam gua tanpa berfikir panjang Sugriwa menutup goa tersebut. Subali beranggapan Sugriwa sengaja menutup pintu gua untuk mendapatkan Dewi Tara. Pada cerita lain penutupan goa dimaksudkan sebagai upaya Sugriwa menepati pesan Subali jika terjadi darah putih keluar supaya lobang goanya ditutup. Namun hal tersebut tidak dipercaya Subali dan menuduh Sugriwa berbuat curang sehingga pertempuran antar saudara ini tidak bisa dihindari.

Penerapan objek ornamen wayang pada karya Yuliawan dapat dikatakan sebagai karya relief, di Bali sering disebut sebagai karya pandil. Pada karya-karya ini objek wayang dibuat lebih menonjol dari pada badan keramik, sehingga tampilan figure wayang terlihat lebih jelas dan diperkuat dengan penerapan warna. Penonjolan yang dimaksud adalah ketebalan ornamen beberapa melimeter sebagai akibat proses 
perwujudan yang dilakukan dengan teknik tempel, kemudian dibuat detail dengan teknik ukir sesuai figure yang digambarkan. Ketebalan relief pada karyakarya ini dapat dikatakan sebagai katagori relief rendah (low relief). Alamsyah (2018:39) menjelaskan relief rendah adalah relief yang kedalamannya kurang dari setengah dari objek yang digambarkan. Relief lazim dikenal sebagai seni pahat tiga dimensi, umumnya dibuat di atas media batu atau media lainnya yang memiliki nilai sejarah kuno seperti bangunan kuil, candi, monumen dan bangunan lainnya.

Beberapa karya Yuliawan menampilkan warna objek wayang yang kontras dengan latar belakang, sehingga visualisasi motif wayang menjadi sangat jelas dan kontras. Warna-warna gelap sering diambil sebagai latar belakang penciptaan karya ini untuk menampilkan kesan objek wayang lebih dominan. Latar belakang gelap membuat penonjolan objek wayang semakin jelas. Penerapan warna pada objek wayang pada karya-karya Yuliawan tidak terlihat merujuk pada referensi warna wayang khas Bali seperti warna style wayang Kamasan, namun menerapkan warna sesuai keinginan penciptanya. Cat yang digunakan untuk mewarnai karya ini merupakan warna khusus untuk melukis karya keramik buatan pabrik yang dapat dibeli di toko-toko penjual cat warna. Berbeda dengan bahan pewarna lukisan wayang Kamasan sebagian besar diambil dari alam, seperti mangsi untuk warna hitam; blau untuk warna biru yang dibuat dari daun taum; atal (sejenis batu yang banyak didapat dari gunung berapi untuk warna kuning; kunyit untuk warna kuning tua; kencu untuk warna merah tua; tulang atau tanduk menjangan untuk warna putih (Nirma, 2010).

Visual karya-karya ini memberikan gambaran kepada publik sebagai apresiator, penikmat seni, ataupun sebagai calon konsumen, bahwa karya-karya tempat lampu ini dikerjakan dengan ketelitian dan kerumitan yang cukup tinggi, dibuat dengan hati-hati dan memperhatikan detail yang baik. Kerumitan disebut juga ngrawit yaitu sangat rumit, dikerjakan dengan penuh ketelitian, dengan sabar dan hati-hati (Alamsyah, 2018:40). Pada proses penciptaan karya ini juga sangat mempertimbangkan pemenuhan fungsi karya sebagai hal yang utama dan semaksimal mungkin dirancang untuk mampu menampilkan karya yang unik dan menarik, seperti contoh karya yang terlihat pada gambar 2 dan 3 di bawah.

Figur-figur wayang yang dipilih sebagai objek ornamen pada penciptaan karya Yuliawan tergambar dalam suatu penggalan kisah cerita yang diwakili oleh tokoh-tokoh tersebut. Pada gambar 2 di bawah dinarasikan dan divisualkan cerita Hanoman dan Rahwana berseteru karena Hanoman bermaksud menyelamatkan Dewi Sita yang disekap di taman Soka, Alengka. Hanoman adalah anak dari Batara Bayu dengan Dewi Anjani. Hanoman dikisahkan mempunyai kekuatan yang tidak ada bandingannya, tidak ada senjata yang mampu membunuh dirinya. Hanoman juga dikisahkan memiliki kemampuan mengubah diri menjadi besar sebesar gunung atau mengecil seperti anak monyet sesuka hatinya. Di samping itu Hanoman juga mempunyai perwatakan yang baik seperti pemberani, sopan-santun, setia, prajurit ulung, waspada, pandai berbahasa, rendah hati, kuat dan tabah (Sudjarwo, dkk, 2010: 234).

Tokoh Rahwana yang digambarkan pada karya di atas merupakan putra dari Rsi Wisrama dengan Dewi Sukesi. Dewi Sukesi adalah putri Prabu Sumali, raja Alengka. Rahwana adalah figur yang dipakai untuk menyampaikan pesan yang tidak baik, misalnya sifat angkara murka, serakah, tamak sekaligus lambang sifat ulet dalam mengejar cita-cita. Tokoh ini dianggap mewakili sikap keserakahan karena menghalalkan segala cara untuk mencapai tujuannya, ia bisa dan tega mengorbankan siapa pun. Rahwana juga dikisahkan memiliki kekuatan atau kesaktian luar dari biasanya, yaitu tidak akan mati semasih jasadnya menyentuh tanah (Sudjarwo, dkk, 2010: 266 ).

\section{KESIMPULA DAN SARAN}

\section{Kesimpulan}

Karya-karya keramik di atas memberikan pemahaman bahwa motif wayang khas Bali sangat menginpirasi kriyawan dalam penciptaan karya-karya keramik yang unik dan menarik. Penciptaan motif wayang khas Bali pada media keramik masih sangat jarang dilakukan oleh para kriyawan keramik. Kriyawan keramik menerapkan ornamen wayang khas Bali pada media keramik dilakukan dengan berbagai teknik misalnya teknik lukis, teknik ukir dan teknik toreh. Tokohtokoh wayang yang sering diangkat dalam penciptaan karya keramik ini adalah tokoh-tokoh yang populer, tokoh-tokoh yang lumrah secara umum dikenal masyarakat luas. Tokoh-tokoh tersebut ditampilkan pada suatu adegan singkat seri ceritera Ramayana maupun Mahabrata. Tokoh-tokoh pewayangan tersebut misalnya tokoh Rama, Sinta, Laksmana, Anoman, Bima, dan Arjuna. Ornamen khas tradisi pada media keramik ini mampu menjadi pembeda di tengah maraknya keramik bernuansa Cina di Indonesia. Namun kalau dilihat dari visual keramik Cina yang dipasarkan di Indonesia, nampaknya 


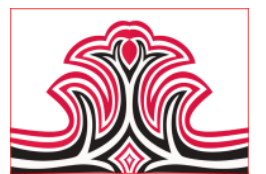

kriyawan keramik ini masih belum mampu mengimbangi dominasi kuasa kualitas dan kuantitas yang ditampilkan keramik Cina.

\section{Saran}

Penciptaan-penciptaan kriya keramik yang bernuansa budaya tradisi dari berbagai daerah di Indoensia perlu terus didorong untuk memunculkan karya-karya keramik berkarakter Indonesia. Pihak-pihak yang memiliki kuasa dalam hal ini bisa melakukan berbagai langkah seperti pembinaan perajin, pemberian modal usaha, melakukan lomba produk kriya bernuansa tradisi, kriya pemberian pemahaman pentingnya pelesatarian budaya melalui karya kriya, serta tindakan nyata yang lainnya.

\section{DAFTAR RUJUKAN}

Alamsyah. (2018). "Potret Pekerja Kerajinan Seni Ukir Relief Jepara”. Endogami: Jurnal Ilmiah Kajian Antropologi, 2(1), p.37. Diunduh 29 April $2019 \quad$ dari https://ejournal.undip.ac.id/index.php/endogami/ article/view/21302.

Arthanegara, I G B. (1977). Wayang Kulit Koleksi Museum Bali. Denpasar: Proyek Pengembangan Media Kebudayaan Ditjen Kebudayaan Departemen P dan K Republik Indonesia.

Arthanegara, I G B, Alit Widiastuti. (1980/1981). Lukisan Wayang Kamasan Koleksi Museum Bali. Denpasar: Proyek Pengembangan Permoseuman Bali.

Atika. (2017). "Mintaqulburuj". Pusat Penelitian Arkeologi Nasional Kemendikbud. Diunduh 9 April 2019 dari http://arkenas.kemdikbud.go.id/contents/read/arti cle/jbqofa 1519878107/mintaqulburuj

Isnaini, S. K., I N. Lodra. (2016). Bentuk, Teknik, Dan Fungsi Ragam Hias Keramik Pada Coco Karunia Keramik Probolinggo. Jurnal Pendidikan Seni Rupa, 04(01), p.137. Diunduh $10 \quad$ April $2019 \quad$ dari http://jurnalmahasiswa.unesa.ac.id/index.php/va/ article/view/15011/13586.

Kanta. I Made. (1977/1978). Proses Melukis Tradisional Wayang Kamasan. Denpasar: Proyek Sasana Budaya Bali.

Martono. (2015). Nilai-Nilai Tradisi sebagai Inspirasi Pengembangan Desain Kriya Kontemporer. Imaji: Jurnal Seni dan Pendidikan Seni, 8(1). Diunduh 30 April 2019 dari doi:https://doi.org/10.21831/imaji.v8i1.6655.

Mudana, I. W. (2017). "Inovasi Bentuk Lukisan Wayang Kamasan". Mudra Jurnal Seni Budaya, 31(2). Diunduh 20 April 2019 dari https://doi.org/10.31091/mudra.v31i2.31.

Mudra, I., P, I., \& CK, I. (2019). Dinamika Problematik Artefak Kriya Masa Lalu di Bali
Gorga Jurnal Seni Rupa

Volume 08 Nomor 02 Juli-Desember 2019 p-ISSN: 2301-5942 | e-ISSN: 2580-2380

pada di Era Revolusi Industri 4.0. Senada (Seminar Nasional Desain Dan Arsitektur), 2, 183-189. Retrieved from https://eprosiding.stdbali.ac.id/index.php/senada/article/view/180

Mulyono, Sri. (1978). Wayang Asal Usul, Filsafat dan Masa Depannya. Jakarta: Gunung Agung.

Nurgiyantoro, Burhan. (2011). "Wayang dan Pengembangan Karakter Bangsa". FBS Universitas Negeri Yogyakarta. Jurnal Pendidikan Karakter, 1(1). Diunduh 24 Maret 2019 dari https://journal.uny.ac.id/index.php/jpka/article/vi ew/1314.

Nirma, I Nyoman. (2010). "Wayang Kamasan II". Diunduh 29 April 2019 dari https://www.isidps.ac.id/berita/wayang-kamasan-ii/.

Sudjarwo, Heru S, Sumari, Wiyono Undung. (2010). Rupa dan Karakter Wayang Purwa. Jakarta: Kaki Langit Kencana.

Tim Penyusun. (1974/1975). Perkembangan Wayang Wong Sebagai Seni Pertunjukan. Denpasar: Proyek Pengembangan Sarana Wisata Budaya Bali. 